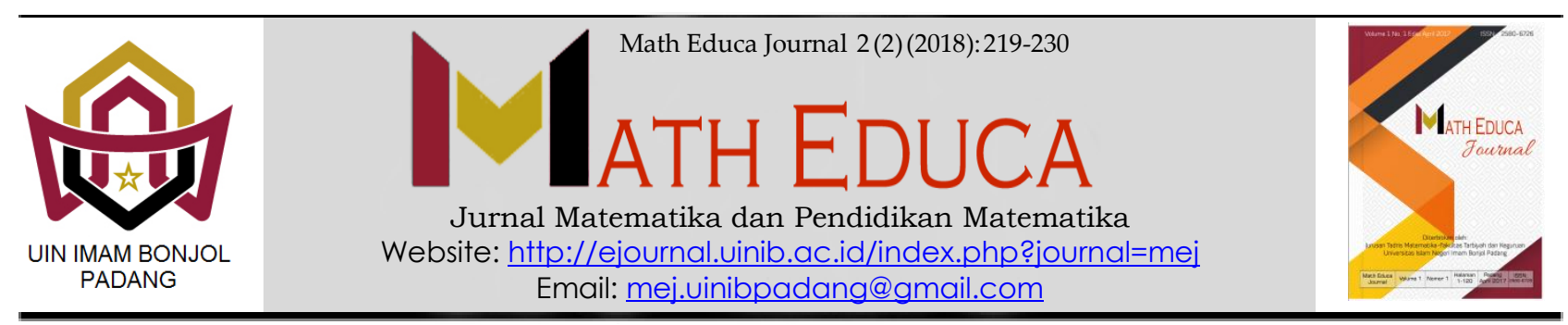

\title{
Analisis Kemampuan Daya Serap Mahasiswa Pada Mata Kuliah Geometri Transformasi
}

\author{
'Darvi Mailisa Putri, 2 Amalina \\ 'Matematika, Fakultas Matematika dan Ilmu Pengetahuan Alam, Univeritas Andalas, Indonesia \\ ${ }^{2}$ Tadris Matematika, Fakultas Tarbiyah dan Keguruan, UIN Imam Bonjol Padang, Indonesia \\ Email:'darvimailisaputri@gmail.com, 2amalina@uinib.ac.id
}

Received: August 2018; Accepted: September 2018; Published: October 2018

\begin{abstract}
Abstrak
Daya serap mahasiswa terhadap materi pembelajaran merupakan salah satu faktor yang dapat mempengaruhi usaha yang dilakukan mahasiswa untuk mencapai capaian pembelajaran. Daya serap dapat menjadi tolak ukur guna mengetahui sejauh mana seorang mahasiswa memahami materi pembelajaran. Oleh karena itu, penelitian ini bertujuan untuk menganalisis tingkat kemampuan daya serap mahasiswa Program Studi Tadris Matematika Fakultas Tarbiyah UIN Imam Bonjol Padang pada mata kuliah geometri transformasi. Penelitian menggunakan pendugaan statistik yaitu kemampuan daya serap mahasiswa pada mata kuliah geometri transformasi paling rendah atau sama dengan $75 \%$ dari nilai maksimum. Analisis data penelitian dilakukan dengan cara manual yaitu dengan menggunakan rumus uji statistik parametrik untuk mengetahui kebenaran pernyataan atau dugaan yang telah dihipotesiskan. Dalam penelitian ini dilakukan uji-z satu sampel dengan satu arah pihak kiri. Selain itu, pengujian hipotesis juga dilakukan dengan menggunakan bantuan aplikasi SPSS. Hasil menunjukan bahwa $-z_{\text {tabel }}=-1,645$ dan $z_{\text {hitung }}=-0,72$. Hal ini berarti $-z_{\text {tabel }} \leq z_{\text {hitung }}$, maka Ho diterima. Dengan demikian dapat diketahui bahwa kemampuan daya serap mahasiswa pada mata kuliah geometri transformasi paling rendah atau sama dengan $75 \%$ dari nilai maksimum. Dengan kata lain ratarata daya serap mahasiswa terhadap mata kuliah geometri transformasi lebih dari atau sama dengan 75. Maka dapat disimpulkan bahwa daya serap mahasiswa pada mata kuliah geometri transformasi cukup baik.
\end{abstract}

Kata kunci: daya serap mahasiswa, geometri transformasi.

\begin{abstract}
The student's absorption of learning material is one of the factors that can influence the efforts of students to achieve learning outcomes. Absorption can be a benchmark for knowing how far a student understands learning material. Therefore, this study aims to analyze the level of absorptive ability of the UIN Imam Bonjol Padang Tarbiyah Faculty of Mathematics Tadris Study Program at the transformation geometry subject. The study uses statistical estimation, namely the ability of the absorption of students in the transformation geometry subject to the lowest or equal to $75 \%$ of the maximum value. The data analysis of the research was carried out manually by using the parametric statistical test formula to find out the truth of the statement or the hypothesis that had been hypothesized. In this study z-test one sample in one direction left side. In addition, hypothesis testing is also carried out using the help of SPSS applications. The results show that and. This means that Ho is accepted. Thus it can be seen that the ability of student absorption in the
\end{abstract}

\section{${ }^{*}$ Corresponding author.}

Peer review under responsibility UIN Imam Bonjol Padang.

(c) 2018 UIN Imam Bonjol Padang. All rights reserved. 
transformation geometry subject is the lowest or equal to $75 \%$ of the maximum value. In other words, the average absorption of students towards transformation geometry courses is more than or equal to 75 . So it can be concluded that the absorption of students in the geometry subject of transformation is quite good.

Keywords: student absorption, transformation geometry.

\section{PENDAHULUAN}

Hasil penilaian dari suatu proses pembelajaran menjadi hal yang begitu penting bagi seorang mahasiswa, karena dari hasil penilaian tersebut mahasiswa akan diberi suatu predikat yang menentukan tingkat keberhasilan mahasiswa dalam mencapai tujuan dan capaian pembelajaran pada suatu mata kuliah. Seseorang yang memiliki peran penting dalam proses ini adalah seorang dosen.

Selain berperan sebagai pengajar, dosen juga memiliki peran sebagai evaluator atau penilai. Dalam segi penilaian, dosen harus memiliki kemampuan menilai semua unsur yang bisa dijadikan sebagai hasil akhir dalam proses pembelajaran. Untuk mendapatkan hasil belajar yang baik tidak terlepas dari proses belajar mengajar yang seharusnya berjalan dengan maksimal, dosen sebagai fasilitator diharapkan mampu untuk membimbing dan mengarahkan peserta didik menjadi manusia yang lebih baik melalui materi-materi yang disampaikannya. Agar hal tersebut tercapai, maka seorang dosen harus mengetahui masalah-masalah yang dapat mempengaruhi kemampuan daya serap peserta didik untuk menerima materi pembelajaran karena Setiap mahasiswa mempunyai keunikannya masing-masing. Namun demikian, berbicara tentang kompetensi maka setiap pembelajaran mensyaratkan bahwa setiap siswa minimal mampu memahami sekaligus mengerti apa yang menjadi kewajibannya. Daya serap merupakan salah satu faktor yang dapat mempengaruhi usaha yang dilakukan seseorang. Daya serap yang kuat atau tinggi akan menimbulkan usaha yang mudah dan tidak sulit dalam menghadapi masalah atau problem. Jika seorang siswa memiliki daya serap tinggi terhadap mata pelajaran yang disampaikan oleh guru maka dengan cepat ia dapat mengerti, memahami dan mengingatnya.

Selain itu, mahasiswa juga harus memiliki daya serap yang cukup baik dalam mengikuti proses pembelajaran. Daya serap adalah kemampuan atau kekuatan untuk melakukan sesuatu untuk bertindak dalam menyerap pelajaran (Kamus Besar Bahasa Indonesia, 1990:15). Daya serap ini menjadi tolak ukur guna mengetahui sejauh mana seorang mahasiswa paham dengan mata kuliah yang sedang mereka ambil. Oleh karena itu, peningkatan daya serap menjadi hal yang 
menarik untuk diteliti. Pada tahun 2009, Wasidi melakukan penelitian yang berkaitan peningkatan daya serap materi evaluasi pendidikan dengan latihan terbimbing. Selain itu, terdapat juga penelitian mengenai analisis kemampuan mahasiswa yang diteliti oleh Ridwan pada tahun 2015 .

Terdapat dua faktor yang mempengaruhi daya serap, yaitu faktor intern dan ekstern. Dimana faktor intern adalah faktor yang timbul dari diri sendiri sedangkan faktor ekstern merupakan faktor yang timbul dari luar diri. Faktor intern diataranya adalah faktor yang timbul dari fisiologi, psikologi, dan pengalaman dasar seseorang. Namun, untuk faktor ekstern merupakan faktor yang berasal dari keluarga, kampus dan masyarakat (Mustaqim, 2001:90).

Dengan mengetahui daya serap mahasiswa terhadap materi pembelajaran berdasarkan hasil belajar mahasiswa, maka dosen dapat mengetahui seberapa besar minat mahasiswa dalam proses pembelajaran sehingga dosen dapat mengevaluasi proses pembelajaran yang telah berlangsung guna untuk pembelajaran selanjutnya yang lebih optimal sehingga diperoleh hasil belajar yang optimal.

Dalam proses pembelajaran di suatu universitas, terdapat beberapa mata kuliah yang harus diikuti oleh mahasiswa guna menunjang pengetahuan dan perkembangan untuk dapat berpikir logis dan sistematis. Salah satu mata kuliah yang diwajibkan adalah mata kuliah geometri transformasi. Mata kuliah ini merupakan mata kuliah yang berkaitan erat bidang kajian ilmu matematika.

Geometri tranformasi merupakan pemetaan satu-satu dengan menggunakan himpunan titik-titik sebagai masukan/input dan returning point sebagai keluaran/output (Meyta dan Isnaini, 2017:1). Himpunanhimpunan input tersebut dinamakan sebagai objek dan output yang bersesuaian dinamakan sebagai bayangan/image. Selain itu, transformasi juga dapat diartikan sebagai proses mengubah titik koordinat menjadi titik koordinat lain pada bidang tertentu. Transformasi tidak hanya terhadap titik tetapi bisa juga dilakukan pada kumpulan titik yang membentuk bidang atau bangun tertentu.

Geometri transformasi mengalami perkembangan pada tahun 1849-1925 yang dipelopori oleh seorang matematikawan Jerman yang dikenal dengan nama Felix Klein. Klein menciptakan teori awal dari geometri transformasi melalui sebuah jurnal yang bernama Erlangen Program pada tahun 1872. Pada jurnal ini dijelaskan bahwa bangun ruang dan bangun datar juga bisa dikembangkan lewat sumbu simetri yang terdapat pada setiap bangun. Melalui tulisan Klein inilah akhirnya geometri transformasi menjadi sebuah pengaruh yang besar bagi perkembangan matematika modern. 
Berdasarkan uraian tersebut dapat disimpulkan bahwa mata kuliah geometri transformasi menjadi salah satu mata kuliah yang menjadi perhatian untuk dikaji. Pada penelitian ini, peneliti akan mengkaji dan menganalisis hasil pembelajaran mahasiswa terhadap mata kuliah geometri transformasi. Penelitian ini akan dilakukan pendugaan dengan statistik bagaimana kemampuan daya serap mahasiswa pada mata kuliah geometri. Peneliti mengambil data dari beberapa mahasiswa mata kuliah geometri trasnformasi pada semester genap tahun 2017/2018.

Adapun tujuan dari penelitian ini adalah untuk menganalisis kemampuan daya serap mahasiswa pada mata kuliah geometri transformasi. Pada penelitian ini ditetapkan bahwa kemampuan daya serap mahasiswa pada mata kuliah geometri trasnformasi paling rendah atau sama dengan $75 \%$ dari nilai maksimum.

Selanjutnya dari hasil yang telah diperoleh nanti, dapat memberikan manfaat kepada mahasiswa maupun dosen itu sendiri. Hasil penelitian akan menunjukkan seberapa besar minat mahasiswa terhadap pembelajaran dan apakah dugaan yang telah ditetapkan di awal benar atau tidak. Jika tidak, maka mahasiswa dan dosen yang bersangkutan harus lebih mengkaji ulang bagaimana sistem penilaian atau metode pembelajaran yang telah diberikan kepada mahasiswa. Selain itu, mahasiswa juga harus lebih memiliki trik atau metode belajar untuk mendapatkan nilai yang memuaskan guna membuat predikat yang lebih baik kepada diri sendiri. Jika hasil dugaan penelitian benar, maka dapat disimpulkan bahwa daya serap mahasiswa pada mata kuliah geometri transformasi cukup baik dan secara tidak langsung dapat diketahui juga bahwa geometri transformasi masih diminati sampai sekarang di bangku pendidikan serta masih berkontribusi dalam perkembangan ilmu pengetahuan pada saat ini.

\section{METODE PENELITIAN}

\section{Jenis Penelitian}

Metode penelitian adalah cara kerja untuk mengeumpulkan data dan kemudian mengolah data sehingga menghasilkan data yang dapat menyelesaikan masalah penelitian. Metode penelitian merupakan cara utama yang dipergunakan untuk mencapai suatu tujauuan, misalnya untuk menguji serangkaian hipotesa, dengan mempergunakna teknik serta alat tertentu. Cara utama ini dipergunakan setelah penyelidik memperhitungkan kewajarannya ditinjau dari tujuan penyeledikan dan situasi penyelidikan.

Penelitian ini merupakan penelitian deskriptif pendekatan kuantitatif. Metode penelitian kuantitiatif merupakan salah satu jenis penelitian yang spesifikasinyaadalah sistematis, terencana, dan terstruktur dengan 
jelas sejak awal hingga pembuatan desain penelitiannya.

\section{Waktu dan Tempat Penelitian}

Penelitian ini dilakukan di UIN Imam Bonjol Padang yang dilaksanakan pada matakuliah Geometri Transformasi. Penelitian dilaksanakan pada Bulan Juli 2018.

\section{Populasi dan Sampel}

Populasi dalam penelitian ini adalah seluruh mahasiswa UIN Imam Bonjol Padang, bagian dari populasi pada penelitian ini adalah seluruh mahasiswa Tadris Matematika Fakultas Tarbiyah UIN Imam Bonjol Padang. Sampel pada penelitian ini adalah mahasiswa semester genap 2017/2018 Tadris Matematika Fakultas Tarbiyah UIN Imam Bonjol Padang yang mengikuti mata kuliah geometri transformasi.

Adapun teknik yang digunakan dalam pengambilan sampel pada penelitian ini adalah teknik purposive sampling, yaitu penentuan sampel dengan pertimbangan/tujuan tertentu (Sugiono, 2012:124). Sampel pada penelitian ini adalah mahasiswa kelas A dan B semester genap Tahun Akademik 2017/2018 Program Studi Tadris Matematika Fakultas Tarbiyah dan Keguruan UIN Imam Bonjol Padang yang mengikuti perkuliahan geometri transformasi.

\section{Prosedur}

\section{Tahap Persiapan}

a) Menentukan kelas yang akan dijadikan subjek penelitian.

b) Mengumpulkan data penelitian yang berkaitan dengan hasil belajar mahasiswa mata kuliah geometri transformasi semester genap 2017/2018.

c) Menentukan hipotesis atau dugaan sementara dari data penelitian yang berkaitan dengan nilai rata-rata daya serap materi kuliah geometri transformasi mahasiswa semester genap $2017 / 2018$.

\section{Tahap Pelaksanaan}

a) Melakukan pengujian data penelitian berupa uji normalitas dan homogenitas untuk melihat apakah data penelitian berdistribusi normal

b) Menentukan taraf signifikan

C) Melakukan prosedur pengujian hipotesis sesuai data penelitian

\section{Tahap Penyelesaian}

a. Melakukan analisis terhadap hasil belajar mahasiswa berdasarkan hasil pengujian hipotesis

b. Melakukan pembahasan dan menarik kesimpulan dari hasil analisis data.

c. Menyusun laporan hasil penelitian, menuliskan kesimpulan akhir mengenai daya serap materi pembelajaran mata 
kuliah geometri transformasi terhadap mahasiswa semester genap 2017/2018 program studi tadris matematika Fakultas Tarbiyah UIN Imam Bonjol Padang.

\section{Data, Intrumen, dan Teknik Pengumpulan Data}

Data pada penelitian ini merupakan data kuantitatif yaitu berupa nilai akhir mahasiswa semester genap 2017/2018 Program Studi Tadris Matematika Fakultas Tarbiyah dan Keguruan UIN Imam Bonjol Padang pada mata kuliah geometri transformasi yang digunakan untuk dilakukan uji normalitas, homogenitas dan uji hipotesis penelitian.

Sumber data dalam penelitian ini adalah dari dosen mata kuliah geometri transformasi program studi tadris matematika fakultas tarbiyah dan keguruan UIN Imam Bonjol Padang. Dalam penelitian ini teknik yang digunakan dalam pengumpulan data adalah dokumentasi. Dokumentasi pada penelitian ini berupa hasil nilai akhir mahasiswa.

\section{Teknik Analisis Data}

Untuk melihat apakah data nilai akhir mahasiswa berdistribusi normal atau tidak dilakukan dengan menggunakan program SPSS. Sehingga diperoleh data nilai akhir mahasiswa berdistribusi normal. Setelah mengetahui data berdistribusi normal, maka dilanjutkan dengan analisis data.
Analisis data penelitian dilakukan dengan cara manual yaitu dengan menggunakan rumus uji statistik parametrik untuk mengetahui kebenaran pernyataan atau dugaan yang telah dihipotesiskan. Dalam penelitian ini dilakukan uji-z satu sampel dengan satu arah pihak kiri. Selain itu, pengujian hipotesis juga dilakukan dengan menggunakan bantuan aplikasi SPSS. Adapun prosedur manual menggunakan uji-z pada adalah sebagai berikut (Syofian, 2012:210):

a) Membuat hipotesis atau dugaan sementara dalam penelitian

b) Membuat hipotesis dalam bentuk model statistik

c) Menentukan taraf signifikan (a) yaitu 5\%

d) Menghitung nilai $z$ hitung dengan rumus:

$$
z_{\text {hitung }}=\frac{\bar{x}-\mu_{0}}{\sigma / \sqrt{n}}
$$

Keterangan:

$\bar{x}=$ rata-rata nilai hasil belajar mahasiswa

$\mu_{0}=$ nilai rata-rata ideal

$\sigma=$ standar deviasi

$n=$ jumlah populasi

e) Menghitung nilai z tabel

f) Menentukan kaidah/kriteria pengujian hipotesis yaitu:

Jika: $-z_{\text {tabel }} \leq z_{\text {hitung }}$, maka Ho diterima

Jika: $-z_{\text {tabel }}>z_{\text {hitung }}$, maka Ho ditolak

Atau dapat dilihat berdasarkan gambar berikut: 


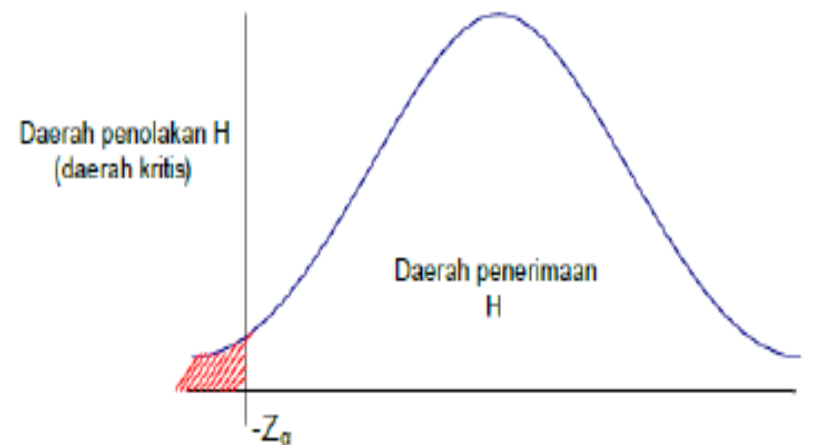

Gambar 1. Kurva Normal uji-z variabel dengan satu arah pihak kiri.

g) Mengambil keputusan berdasarkan kriteria pengujian

\section{HASIL PENELITIAN DAN PEMBAHASAN}

Pada bagian ini akan dibahas hasil penelitian yang dilakukan terhadap 50 mahasiswa pada mata kuliah geometri transformasi. Pada data yang telah didapat akan dianalisis kemampuan daya serap mahasiswa terhadap mata kuliah geometri transformasi. Selanjutnya dilakukan dugaan bahwa kemampuan penyerapan materi kuliah mahasiswa untuk mata kuliah geometri transformasi paling rendah atan sama dengan 75\% dari nilai maksimum. Berikut data nilai akhir mahasiswa mata kuliah geometri trasnsformasi.

Tabel 1. Tabel Analisis Kemampuan Mahasiswa terhadap Mata Kuliah Geometri Transformasi.

\begin{tabular}{ccc}
\hline No & Nilai Akhir & Huruf Mutu \\
\hline 1 & 76,00 & B \\
2 & 73,00 & B \\
3 & 77,50 & B \\
4 & 71,50 & B \\
5 & 74,50 & B \\
\hline
\end{tabular}

\begin{tabular}{|c|c|c|}
\hline No & Nilai Akhir & Huruf Mutu \\
\hline 6 & 74,50 & B \\
\hline 7 & 73,00 & B \\
\hline 8 & 74,50 & B \\
\hline 9 & 74,50 & B \\
\hline 10 & 80,20 & $A$ \\
\hline 11 & 74,50 & B \\
\hline 12 & 73,00 & B \\
\hline 13 & 73,00 & B \\
\hline 14 & 71,50 & B \\
\hline 15 & 70,00 & B \\
\hline 16 & 77,50 & B \\
\hline 17 & 74,50 & B \\
\hline 18 & 79,00 & B \\
\hline 19 & 78,10 & B \\
\hline 20 & 76,30 & B \\
\hline 21 & 72,60 & B \\
\hline 22 & 74,40 & B \\
\hline 23 & 68,10 & $C$ \\
\hline 24 & 68,50 & $C$ \\
\hline 25 & 80,50 & $A$ \\
\hline 26 & 79,00 & B \\
\hline 27 & 67,30 & $C$ \\
\hline 28 & 76,90 & B \\
\hline 29 & 77,50 & B \\
\hline 30 & 77,50 & B \\
\hline 31 & 74,50 & B \\
\hline 32 & 73,00 & B \\
\hline 33 & 72,10 & B \\
\hline 34 & 70,00 & B \\
\hline 35 & 77,50 & B \\
\hline 36 & 73,60 & B \\
\hline 37 & 73,90 & B \\
\hline 38 & 76,00 & B \\
\hline 39 & 74,50 & B \\
\hline 40 & 70,00 & B \\
\hline 41 & 80,50 & $A$ \\
\hline 42 & 74,50 & B \\
\hline 43 & 73,90 & B \\
\hline 44 & 79,00 & B \\
\hline 45 & 75,40 & B \\
\hline 46 & 77,50 & B \\
\hline 47 & 76,00 & B \\
\hline 48 & 70,30 & B \\
\hline 49 & 71,50 & B \\
\hline 50 & 80,50 & A \\
\hline
\end{tabular}

Berdasarkan data yang digambarkan pada Tabel 1, dapat dilihat bahwa sebagian 
besar nilai akhir mahasiswa baik pada mata kuliah geometri transformasi. Lebih rincinya akan digambarkan pada Tabel 2.

Tabel 2. Tabel Analisis Kemampuan Mahasiswa terhadap Mata Kuliah Geometri Transformasi.

\begin{tabular}{llc}
\hline No & \multicolumn{1}{c}{ Kategori } & Jumlah Orang \\
\hline 1 & Sangat Baik & 4 \\
2 & Baik & 43 \\
3 & Cukup Baik & 3 \\
4 & Kurang Baik & 0 \\
5 & Sangat Kurang & 0 \\
\hline
\end{tabular}

Berdasarkan data yang ada pada Tabel 2, hal ini menunjukkan bahwa daya serap mahasiswa terhadap mata kuliah geometri transformasi cukup baik yaitu terdapat 4 mahasiswa dengan kategori sangat baik, 43 mahasiswa dengan kategori baik, dan 3 mahasiswa dengan kategori cukup baik. Sedangkan untuk kategori kurang baik dan sangat kurang terdapat o mahasiswa. Selain data dari tabel 2, lebih jelasnya dapat dilihat pada diagram berikut dengan rincian kategori sangat baik terdapat $8,00 \%$, kategori baik $86,00 \%$ dan kategori cukup baik 6,00\%. Sedangkan 0\% untuk kategori kurang baik dan sangat kurang.

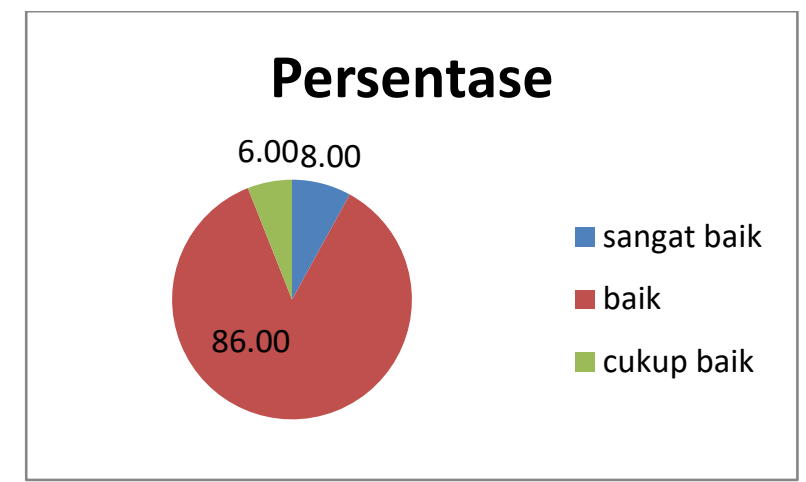

Gambar 2. Persentase Daya Serap Mahasiswa terhadap Mata Kuliah Geometri Transformasi.
Setelah melakukan analisis terhadap data 50 mahasiswa pada mata kuliah geometri transformasi. Selanjutnya, pada data dilakukan uji-z variabel dengan satu arah pihak kiri untuk membuktikan dugaan bahwa kemampuan penyerapan materi kuliah mahasiswa pada mata kuliah geometri transformasi paling rendah atau sama dengan $75 \%$ dari nilai maksimum.

Sebelum melakukan uji-z, diperiksa terlebih dahulu apakah data berdistirbusi normal atau tidak dengan menggunakan software SPSS. Cara uji normalitas dengan software SPSS dapat dilakukan dengan uji Shapiro Wilk atau liliefors serta KolmogorovSmirnov. Berikut hasil output dari SPSS.
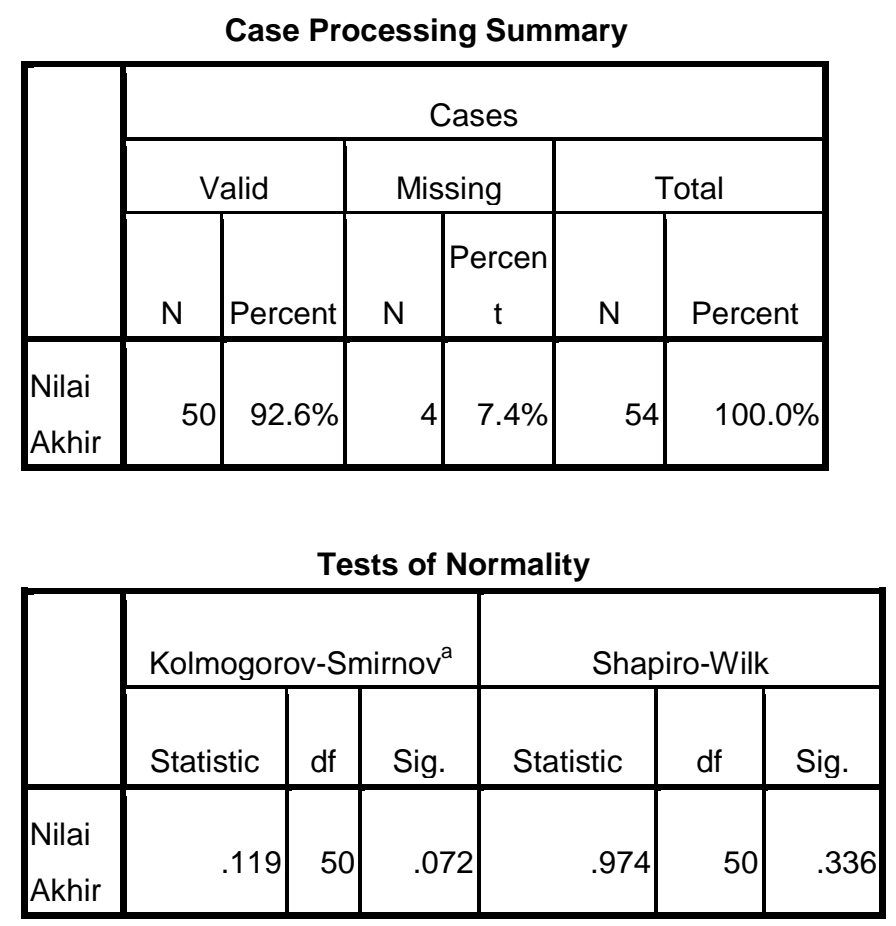

a. Lilliefors Significance

Correction 


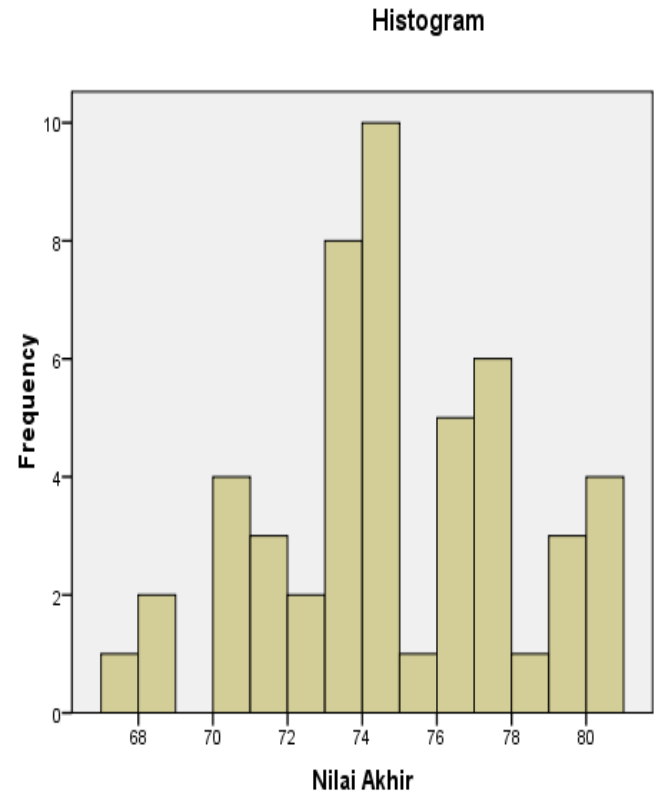

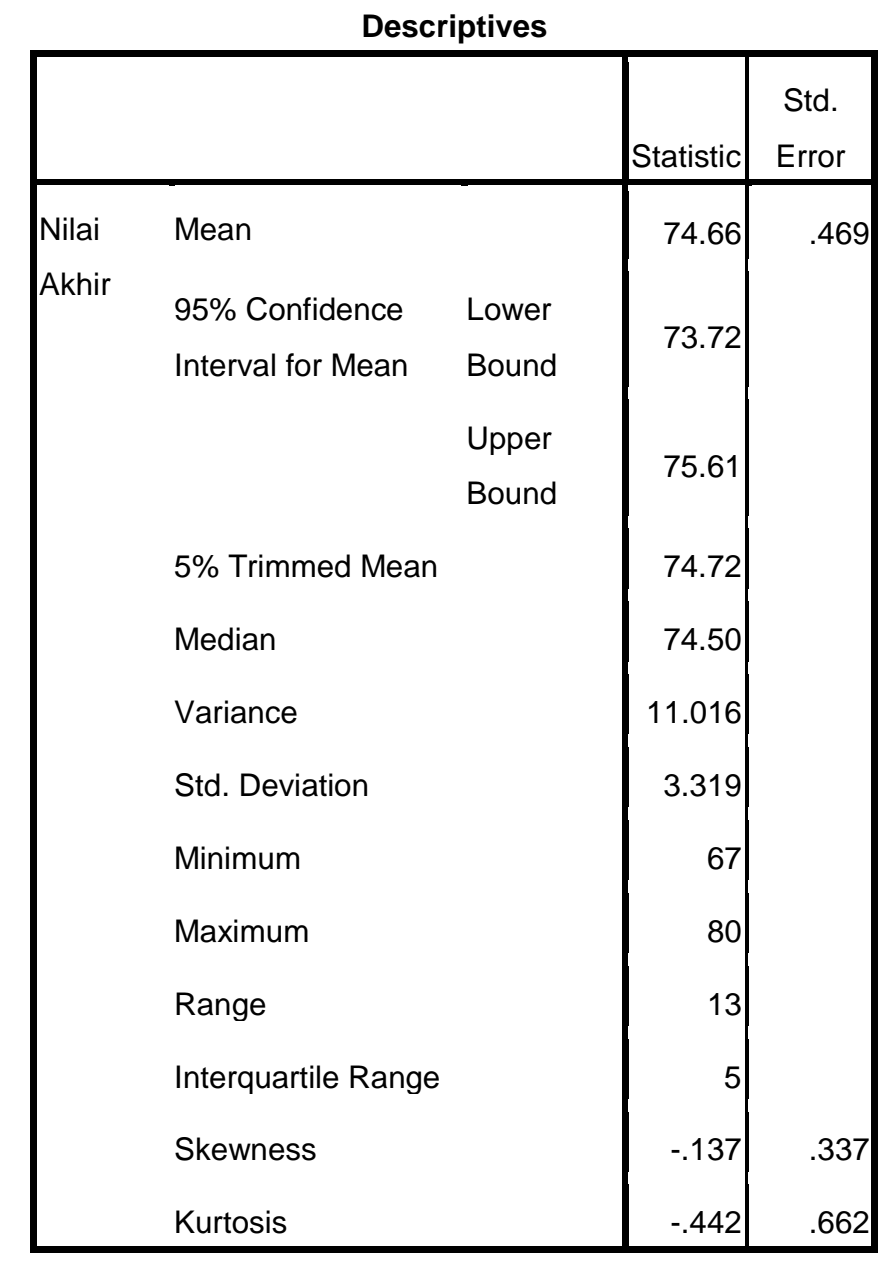

Pada hasil yang ditampilkan SPSS pada uji normalitas Shapiro Wilk, nilai sig atau nilai signifikansi yang diperoleh adalah 0,336. Hal ini dapat dikatakan bahwa data berdistribusi normal karena nilai signifikansi yang didapat lebih dari 0,05. Begitu juga pada uji normalitas Kolmogorov-Smirnov yang menyatakan bahwa data berdistribusi normal, karena nilai signifikansi yang didapat sebesar 0,072 yaitu lebih dari 0,05.

Selain dari uji normalitas Shapiro Wilk dan Kolmogorov-smirnov, untuk melihat data berdistribusi normal dapat juga dilihat dari histogram. Pada histogram terlihat jelas bahwa data berdistribusi normal karena susunan data membentuk seperti hal nya kurva distribusi normal.

Langkah penelitian selanjutnya adalah melakukan uji-z. Adapun tahap-tahapnya sebagai berikut.

Pertama, membuat hipotesis dalam uraian kalimat, yaitu Ho dan Ha. Pada kasus ini ditetapkan bahwa Ho adalah kemampuan daya serap mahasiswa pada mata kuliah geometri transformasi paling rendah atau sama dengan 75\% dari nilai maksimum. Sedangkan Ha adalah kemampuan daya serap mahasiswa pada mata kuliah geometri transformasi paling tinggi 75\% dari nilai maksimum.

Langkah kedua, membuat hipotesis pada model statistik, yaitu

$$
\begin{aligned}
& H o: \mu \geq 75 \\
& H a: \mu<75
\end{aligned}
$$

dimana $\mu$ adalah nilai dugaan dan 75 adalah objek penelitian. 
Tahap ketiga, menentukan taraf signifikan. Hal ini bertujuan untuk menentukan seberapa besar peluang membuat risiko menolak hipotesis yang benar. Pada penelitian ini ditetapkan taraf signifikan sebesar 5\%.

Selanjutnya menentukan nilai $z_{\text {hitung }}$ dengan terlebih dahulu menentukan nilai mean dan standar deviasi menggunakan formula sebgai berikut.

$$
\begin{aligned}
& \bar{X}_{i}=\frac{\sum X_{i}}{n} \\
& \sigma=\sqrt{\frac{\sum\left(X_{i}-\bar{X}\right)^{2}}{n}} \\
& z_{\text {hitung }}=\frac{\bar{x}-\mu_{0}}{\sigma / \sqrt{n}}
\end{aligned}
$$

Hasil yang diperoleh, dapat dilihat pada Tabel 3 berikut.

Tabel 5. Tabel Hasil Perhitungan Nilai Akhir Mahasiswa pada Mata Kuliah Geometri Transformasi.

\begin{tabular}{llc}
\hline No & Kategori & Nilai \\
\hline 1 & Mean & 74,66 \\
2 & Standar Deviasi & 3,28 \\
3 & z-hitung & $-0,72$ \\
\hline
\end{tabular}

Selain dengan menggunakan formula tersebut, peneliti juga menggunakan software SPSS untuk mencari nilai z-hitung. Berikut

\begin{tabular}{|c|c|c|c|c|}
\hline & $\mathrm{N}$ & Mean & $\begin{array}{c}\text { Std. } \\
\text { Deviation }\end{array}$ & $\begin{array}{c}\text { Std. Error } \\
\text { Mean }\end{array}$ \\
\hline $\begin{array}{l}\text { Nilai } \\
\text { Akhir }\end{array}$ & 50 & 74.66 & 3.319 & .469. \\
\hline
\end{tabular}
adalah hasil output yang diperoleh.

\section{One-Sample Statistics}

One-Sample Test

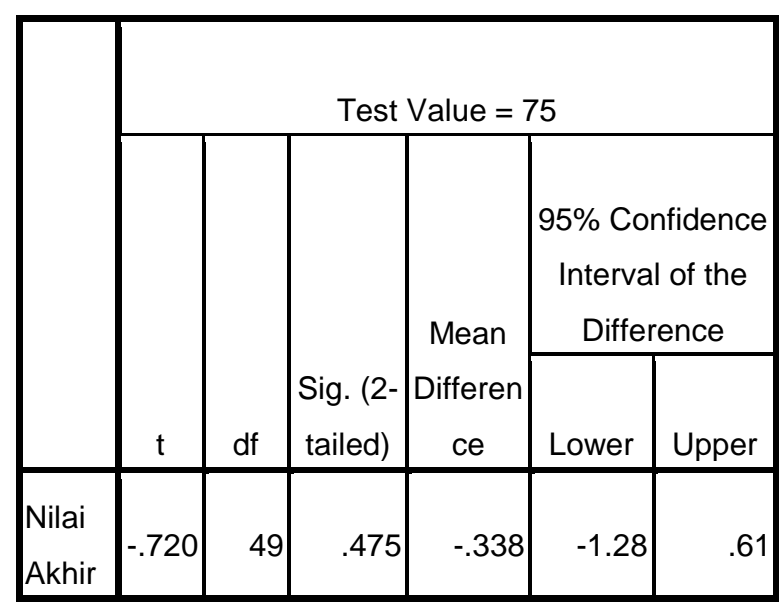

Berdasarkan perhitungan dan pengolahan data yang telah dilakukan diperoleh nilai $z_{\text {hitung }}$ sebesar $-0,72$. Nilai ini akan dibandingkan dengan nilai $z_{\text {tabel }}$. Nilai $z_{\text {tabel }}$ dapat dicari dengan menggunakan tabel distribusi normal dengan formula $1-\alpha=n$. $z_{\text {tabel }}=1-0,05=0,95$. Lalu dicari pada tabel distribusi normal nilai yang sama atau yang mendekati nilai 0,95. Berada pada baris ke berapa dan kolom ke berapa. Nilai 0,95 berada pada baris 1,6 dan diantara kolom ke-4 yaitu 0,9495 dan kolom ke-5 yaitu 0,9505. Berdasarkan hal itu maka diperoleh nilai $z_{\text {tabel }}=1,645$.

Membandingkan $z_{\text {hitung }}$ dan $z_{\text {tabel }}$ guna mengetahui hipotesis Ho diterima atau ditolak. Diperoleh bahwa nilai $z_{\text {hitung }}=-0,72$ dan $z_{\text {tabel }}=1,645$. Berdasarkan kaidah pengujian dari arah kiri dijelaskan bahwa, Jlka: $-z_{\text {tabel }} \leq z_{\text {hitung }}$, maka Ho diterima Jlka: $-z_{\text {tabel }}>z_{\text {hitung }}$, maka Ho ditolak 
Dapat ditarik kesimpulan bahwa $-z_{\text {tabel }} \leq z_{\text {hitung }}$, maka Ho diterima. Dengan demikian dapat diketahui bahwa kemampuan daya serap mahasiswa pada mata kuliah geometri transformasi paling rendah atau sama dengan $75 \%$ dari nilai maksimum. Berikut gambar daerah penerimaan dan penolakan pada uji-z untuk pihak kiri.

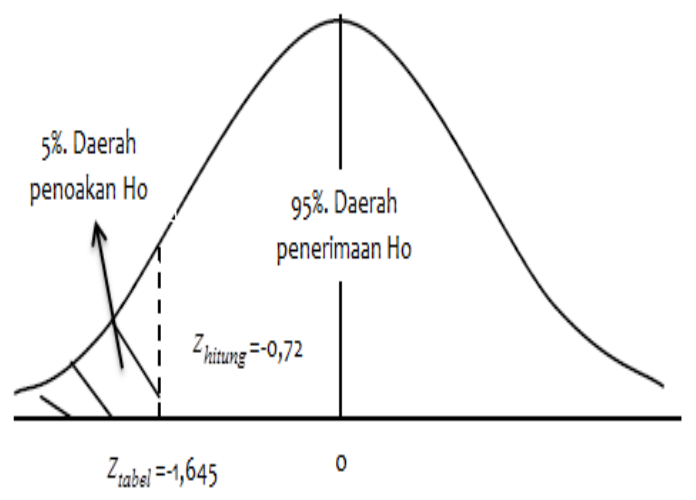

Gambar 3. Penentuan Daerah Penolakan dan Penerimaan pada uji-z untuk pihak kiri.

\section{SIMPULAN DAN SARAN}

\section{Simpulan}

Berdasarkan hasil dan pembahasan yang telah diuraikan maka dapat disimpulkan bahwa,

1. Kemampuan daya serap mahasiswa pada mata kuliah geometri transformasi paling rendah atau sama dengan $75 \%$ dari nilai maksimum dengan kata lain rata-rata daya serap mahasiswa untuk mata kuliah geometri transformasi lebih dari atau sama dengan 75 .
2. Mahasiswa memiliki ketertarikan yang baik dalam memepelajari mata kuliah geommetri transformasi.

\section{Saran}

Dengan mengetahui daya serap mahasiswa terhadap suatu materi pembelajaran dapat menginformasikan tentang seberapa besar motivasi mahasiswa terhadap suatu mata kuliah. Oleh karena itu, disarankan untuk melakukan analisis terhadap daya serap mahasiswa tersebut tidak hanya pada mata kuliah geometri transformasi, namun pada mata kuliah lainnya. Hasil analisis daya serap dapat dijadikan sebagai evaluasi bagi dosen dan mahasiswa sehingga kedepannya memberikan hasil belajar yang lebih baik.

\section{REFERENSI}

Departemen Pendidikan dan Kebudayaan. (1990). Kamus Besar Bahasa Indonesia. Jakarta: Balai Pustaka.

Jusuf, Ridwan. (2015). Analisis Kemampuan Mahasiswa PGSD Semester I dalam Menyelesaikan Soal-Soal Mata Kuliah Konsep Dasar IPA I Pokok Bahasan Sistem Pernapasan dengan Menggunakan Metode Demonstrasi . Jurnal Primaty Program Studi Pendidikan Guru Sekolah Dasar Fakultas Keguruan dan Ilmu Pendidikan Universitas Riau, 4(1), 46-53.

Kurniasih, Meyta Dwi dan Isnaini Handayani. (2017). Tangkas Geometri Transformasi. Jakarta: Universitas Muhamadiyah Prof. Dr. Hamka. 
Mustaqim. (2001). Psikologi Pendidikan. Semarang: Pustaka Belajar.

Siregar, Syofian. (2017). Statistik Parametrik untuk Penelitian Kuantitatif: Dilengkapi dengan dengan Perhitungan Manual dan Aplikasi SPSS versi 17. Jakarta: Bumi Aksara.
Sugiyono, (2012). Metode Penelitian Kuantitatif, Kualitatif dan R\&D. Bandung: Alfabeta.

Wasidi. (2009). Peningkatan Daya Serap Materi Evaluasi Pendidikan dengan Latihan Terbimbing pada Progra Studi PLS FKIP UNIB. Jurnal Kependidikan Triadik, 12(1), 63-7 